\title{
Musik og følelser i danske tv-dokumentarer
}

\author{
Af Iben Have
}

En stor del af tv's sendeflade er ledsaget a underlagningsmusik, men den fär kun ringe opmarksomhed fra både tv-seeren og medieforskningen. Den mest udbredte opfattelse begge steder er, at underlegningsmusikkens funktion er at skabe eller understotte folelser og stemninger $i$ den audiovisuelle kontekst. Men hvordan og hvorfor gor den det, og hører den hjemme i fakta-fremstillinger? Det er nogle af de sporgsmål, der vil blive belyst $i$ denne artikel, der vil argumentere for, at musikken har en vigtig rolle at spille $i$ dokumentarudsendelser både via dens evne til at kommunikere folelsesmassige nuancer og som mulig katalysator for kritisk refleksion.

Artiklen falder $i$ tre dele: Forst foretages nogle analytiske nedslag $i$ dokumentarudsendelsen Nesten en dødsdom - en udsendelse, der $i$ vid udstrakning tematiserer folelser. På baggrund heraf folger et afsnit, der presenterer forskellige teoretiske problemstillinger i forbindelse med relationen mellem musik og folelser. I sidste afsnit fremfores nogle mere generelle overvejelser omkring musikkens rolle og funktion $i$ tv-dokumentarens virkelighedsfremstillinger med inddragelse af eksempler fra udsendelserne Drengene fra Vollsmose og De padofile danskere. Genstandsområdet for analyserne er således den seriøse danske tv-dokumentar, men mange af de teoretiske overvejelser vil galde oplevelsen af underlagningsmusik $i$ audiovisuelle medier generelt. ${ }^{1}$

Tv-mediets musik kan overordnet opdeles i to hovedtyper, som har hver deres måde at kommunikere på. Den ene er de pågående attention-grabbers i form af udsendelsernes, produktionsselskabernes, tv-kanalernes eller reklameprodukternes musikalske varemærker. Den anden type tv-musik, som denne artikel handler om, er den tilbagetrukne underlægningsmusik, et underspil, hvis styrke det er at underspille sin rolle $i$ vores bevidste oplevelse af en audiovisuel narrativ fremstilling, men stadig kommunikere et væld af betydning.

Artiklen udspringer af og trækker på resultaterne fra ph.d.-afhandlingen Det musikalske underspil: En undersogelse af underlagningsmusikkens betydning, belyst gennem den journalistiske to-dokumentar (Have, 2004). ${ }^{2}$ Her var empirien 37 udsendelser fra henholdsvis DR-dokumentar og TV 2 dok. sendt i år 2000. Det viste sig, at der gennemsnitligt var musik og musiklignende lyde (under ét: komponeret nondiegetisk lyd $\left.{ }^{3}\right)$ i ca. en fjerdedel af udsendelsernes tid, og at de 14 udsendelser fra TV 2 dok. brugte næsten dobbelt så meget musik som de 23 fra DR-dokumentar. Forskellen på de to redaktioners musikforbrug skal ikke kommenteres yderligere i denne sammenhæng, men skyldes dog først og fremmest, at der hos DR indgik ni af Lars Engels' observerende dokumentarudsendelser (Historier fra en politistation), der bruger æstetiske virkemidler på en sådan måde, at virkeligheden fremstår så ubearbejdet som muligt. ${ }^{4}$

Samtidig med at musikken har en strukturerende funktion i udsendelsernes forløb i form af åbninger og lukninger, sammenbindinger og markeringer, har musikken også en betydningsgenererende funktion, som opstår i tæet relation til udsendelsernes øvrige udtryk. ${ }^{5}$ Med udgangspunkt i musikken alene kan denne sidstnævnte funktion undersøges ud fra tre musikalske betydningsniveauer: ud fra musikkens egne strukturer (musikkens ekspressivitet), disse strukturers relation til følelsesmæssige strukturer (musikkens emotionalitet) og via musikkens sociokulturelle kodninger, der genereres både i og uden for de audiovisuelle medier. Artiklen her vil først og fremmest fokusere på musikkens emotionalitet, som skabes både i receptionen af det musikalske udtryk og i koblingen mellem musikken og den audiovisuelle kontekst. 


\section{Lydtapetet $\mathrm{i}$ udsendelsen Nasten en dødsdom}

Dokumentarudsendelsen Nesten en dodsdom (TV 2 dok., 2000) er bemærkelsesværdig i sin anvendelse af et meget spraglet og massivt lydtapet bestående af musik og lydeffekter. Udsendelsen varer 43 minutter, og der forekommer komponeret non-diegetisk lyd i ca. 60\% af tiden. Det er den udsendelse fra mit materiale, der anvender mest musik, men samtidig er det den udsendelse, hvor musikken er mest "usynlig", både på grund af den lave lydstyrke, den fragmenterede anvendelse samt sammensmeltningen mellem musik og lydeffekter. Vi lægger ikke mærke til musikken og i hvert fald ikke som "musik", men netop som et tapet af lyd, der går i ét med konteksten.

Handlingsmæssigt er Nesten en dødsdom bygget op omkring et tema om gentests som sygdomsforebyggelse og stiller spørgsmålstegn ved magthavernes og mediernes positive fremstilling af, at vi nu kan kortlægge og analysere de menneskelige gener. Vi følger tre kvinder - Malou (28 år), Marianne (36 år) og Pia (31 år) - der alle er blevet testet positive som bærere af et arveligt sygdomsgen, der med op til $80 \%$ sandsynlighed vil give dem kræft i en ung alder. Udsendelsen går meget tæt på de tre kvinders angst, bekymringer og svære valg, både visuelt ved at filme dem meget tæet på og i kraft af deres egne udtalelser, men ikke mindst via musik og lydeffekter. De tre kvinders historie ledsages af en uforløst historie om en fjerde kvinde (Birgitte, 39 år), der har fået foretaget en gentest, men som endnu ikke kender resultatet, og som vi følger til det forløsende øjeblik, hvor hun får svar på prøverne.

Som de øvrige udsendelser fra DR-dokumentar og TV 2 dok. indledes udsendelsen med et kort anslag, der præsenterer udsendelsens præmis og problemstilling (jf. Harms-Larsen 1990) inden selve titlen vises på skærmen. Herefter følger et præsentationsafsnit af de tre hovedpersoner, efterfulgt af hele 12 navngivne kapitler, som skaber udsendelsens narrative skelet. Udsendelsen lægger stor vægt på de personlige beretninger frem for ekspertudtalelser, og de etiske og politiske spørgsmål bliver hermed bragt ind i en mere personlig og nærværende kontekst, der forskyder udsendelsens underliggende tematik hen mod en mere intim, emotionaliseret oplevelsesjournalistik. En forskydning, der i øvrigt er karakteristisk for den generelle udvikling af den seriøse, journalistiske tv-doku- mentar på dansk public service-tv de seneste år (jf. Ib Bondebjerg (2000, s. 190f).

Der krediteres ingen komponist i udsendelsens slutning, men musikken viser sig først og fremmest at stamme fra ambientkomponisten Harold Budds album Lovely Thunder. Lydeffekterne stammer fortrinsvist fra udgivelsen Sounds of a different realm produceret af lydfolkene bag David Lynchs tv-serie Twin Peaks. Udsendelsen fremstår som en gennemarbejdet audiovisuel helhed, hvilket også bunder i en redigeringproces, hvor der er blevet arbejdet med alle dele af udtrykket samtidig. Musik og lydeffekter er således redigeret ind løbende frem for at blive lagt på til sidst, hvilket er den gængse fremgangsmåde. ${ }^{6}$ Udsendelsens stil er generelt karakteriseret ved en høj puls og dynamik såvel på det auditive som på det visuelle plan, hvilket kommer særligt til udtryk i det komprimerede anslag med en hurtig klipperytme og en lydside skabt af lydeffekter.

Med sine stille droner (fastholdte akkorder) og spacey synthesizers er ambientmusikken i Nesten en dødsdom kendetegnende for størstedelen af den musik, der anvendes som underlægning i DR-dokumentars og TV 2 dok.s udsendelser fra år 2000. ${ }^{7}$ Musikken er elektronisk, men organisk i sin form og giver associationer til naturen ved at ligne lyde og puls, som vi genkender: vinden, bølgerne, vandets rislen, åndedraget, hjerteslaget. Der anvendes mange lydflader (flydeakkorder, droner, susen) og klange, som befinder sig i grænseområdet mellem musik og lydeffekter. Der er ingen fast puls, eller også er den så langsom, at man ikke fornemmer den som puls, men netop som et åndedrag. Denne type musik indeholder næsten ingen markeringer eller attacks, men er flydende med megen rumklang og vibrerende overtoner, der skaber fornemmelsen af store åbne rum. Klangfladerne sniger sig ind og ud mellem hinanden, og der optræder kun få men fyldige musikalske begivenheder ad gangen, samtidig med at dronerne fylder lydbilledet ud i en konstant strøm. Musikkens er flertydig og åben i sit udtryk og fungerer derfor som en kamæleon i forhold til den betydning, der omgiver den. Samtidig er den i bogstaveligste forstand ambient, idet den omslutter både det audiovisuelle udtryk og receptionen af det. I kraft af alle lydeffekterne virker musikken i Nesten en dødsdom mere suspense-agtig, end hvis man lytter til Budds originale indspilninger fra Lovely Thunder. Selvom suspensemusik, som den især kendes fra filmmusikken med dissonerende 
intervaller, kromatik og ostinater, ${ }^{8}$ tilsyneladende er i modsætning til ambientmusikken, da den første bygger spænding op, og den anden forløser, er der også ligheder mellem de to genrer. Både ambient- og suspensemusikken har en evne til at trække lytteren ind i et virtuelt soundscape, et rum der indbyder til et følelsesmæssigt engagement.

Der anvendes fire musikalske temaer i udsendelsen, hvor de tre første stammer fra Budds album, og det fjerde, der kun høres kort, efter al sandsynlighed er af en anden ambientkomponist, Brian Eno. De fire temaer kobler sig i grove træk til hver af de fire kvinder, og er på trods af musikkens ensartethed med til at karakterisere dem og deres historier som forskellige: Tema 1 fra nummeret "Valse pour le fin de temps" knytter sig fortrinsvist til Malou; tema 2 fra nummeret "Olancha Farewell" knytter sig fortrinsvist til Marianne, men anvendes også i forbindelse med Pias historie; tema 3 fra nummeret "Gypsy violin" knytter sig fortrinsvist til Pia; og tema 4 høres i forbindelse med Birgittes historie.

Det er Malous historie, der dominerer udsendelsen, og som indleder og afslutter den. Efter præsentationsafsnittet markeres med skærmteksten "Malou og døden" begyndelsen på det første kapitel, der som nævnt ledsages af temaet "Valse pour le fin de temps", som kendetegnes ved et akkompagnement i mol bestående af diskante (dvs. i et højt toneleje) treklangsbrydninger i en vuggeviseagtig tredelt valsetakt. Da vi første gang hører musikken i dette kapitel, sker det samtidig med, at nærbillederne af Malou på shopping i en tøjbutik trækkes ned i slowmotion i et par sekunder for derefter at fortsætte i den reale tid. Samtidig fortæller Malou i voice over om de tanker, en positiv sygdomsgentest giver anledning til. I denne sekvens oplever vi på grund af de gentagne korte slowmotionforløb, at vi suges ind bag facaden til hendes tanker og følelser, og musikken får en klar kodning i den retning. Treklangsbrydningerne kører i ring om de samme toner ligesom de tanker og følelser, hun giver udtryk for. Der etableres hermed to narrative niveauer: Den dokumenterede, synlige og hørbare shoppingtur med veninden og Malous indre liv af ensomhed, angst og forvirring, som fortrinsvist gengives musikalsk med nedtonede reallyde. Vi veksler ud og ind imellem de to niveauer $\mathrm{i}$ takt med slowmotioneffekten og musikken. Hermed bliver der lydligt/musikalsk gengivet en væsentlig del af denne udsendelses problemstilling nemlig angsten og ensomheden, der også bliver musikkens overordnede betydning i udsendelsen.

Da vi i kapitlet "Mariannes ensomhed" ca. otte minutter henne i udsendelsen møder Marianne i hendes dagligdag som sygeplejerske på et hospital, bygges der en utryg stemning op af reallyde, pulsmålerbip og skarpe dryppelyde. ${ }^{9}$ En uhyggelig sammensat lyd, som jeg kalder ghost song, sætter ind og skaber et kort crescendo hen imod udsendelsens mest rene, harmoniske klang: en ren G-durtreklang spillet med en fyldig hornklang placeret langt fremme i lydbilledet, hvor den fortrænger reallydene. Dette horntema stammer fra nummeret "Olancha Farewell", og da det toner frem, klippes der til en scene, hvor vi ser Marianne, med hovedet lidt på skrå og i slowmotion, se med et meget kærligt blik på sin mor (der selv har været kræftsyg), mens de sidder og drikker kaffe sammen privat. Temaets manglende attack og svulmende fyldige klangmasse i en nedadgående melodisk bevægelse, hvor intensiteten ligger i forløsningen hen imod den rene G-dur, kobler sig til betydningen "et kort øjebliks kærlighed eller ømhed mellem mor og datter". Men der er tale om den tunge, næsten ubærlige side af kærligheden i et tæt mor/datterforhold; en kærlighed der gør ondt, når den anden lider. Temaet klinger kun kort, og med lyden af et forholdsvist kraftigt hjerteslag klippes der tilbage til hospitalshverdagen, hvor en pågående telefons konstante ringen indtager det auditive rum og tvinger os tilbage til den "ydre" virkelighed. Samtidig med at musikken genererer betydning, når den anvendes i klippet med Marianne og hendes mor, bliver den også selv kodet med betydning, og motivet fungerer svagt ledemotivisk udsendelsen igennem. Vi hører fortrinsvist temaet i forbindelse med mor/datter-forholdet, men det udvides til også at gælde Mariannes forhold til sin egen datter i kapitlet "Marianne og fremtiden".

Horntemaet anvendes imidlertid også i kapitlet "Birgittes lange dag" ca. 31 minutter henne i udsendelsen, hvor det optræder i en anden kontekst og dermed făr en anden betydning. Inden klimakset for Birgittes historie (og for hele udsendelsen) følger vi hende fra morgenstunden på den dag, hvor hun skal have svar på sin gentest:

... efter at jeg havde sat min søn af $\mathrm{i}$ børnehaven, så begyndte det lidt igen, den der ...(pause)..., nøjagtig ligesom når man skal til eksamen, hvor man ryster lidt indvendig. 
Lige da hun siger "den der ..." og mangler ord, sætter horntemaet svagt ind og sætter lyd på den nervøsitet, hun mangler ord for. Forudsigeligt nok stiger temaet ligesom nervøsiteten i styrke, jo tættere vi kommer på det tidspunkt, hvor hun får sit svar. Først ser vi slowmotionbilleder af Birgitte uden for Kennedy Instituttet, hvor hun skal have svar på sin gentest. Da hun bliver kaldt ind til lægen, stiger musikken yderligere i styrke og fylder hele det auditive rum ud. Da vi endelig, på baggrund af den lukkede dør, hun er gået ind bag, med undertekst får oplyst, at hun ikke bærer kræftgenet, fader musikken hurtigt ud. Efter et interview med Birgitte, hvor hun taler om lettelsen og om den fysisk ubehagelige efterreaktion, høres et helt nyt tema (udsendelsens fjerde tema), mens vi ser hende i slowmotion omfavne sin lille søn derhjemme. Temaet klinger kun i 28 sekunder og er sammensat af forskellige motiver. Først skabes der en lethed med et lille motiv på forskellige enkeltstående toner, der klangligt lyder som en blanding mellem eksotiske fuglefløjt og dråber i vand. Herefter flader lydbilledet ud i forskellige urolige klangflader, der toner ind og ud strækkende sig fra diskante, skærende klange til dybe, ru strygerlyde. Forløbet illustrerer således Birgittes udsagn fra interviewet og tilfører med klangfladerne den positive billedside en urolig, utryg dimension. Selvom stilen er den samme som i de tre temaer af Budd, skiller dette tema med sine distinkte toner og klarere sound sig ud på samme måde, som Birgittes historie gør det.

Udsendelsens tredje musikalske tema høres første gang sammen med Pias historie ca. 11 minutter henne i udsendelsen. På Budds album hedder indspilningen som nævnt "Gypsy violin", hvilket afspejler temaets mørke strygerklang. Ellers er musikken $\mathrm{i}$ bedste ambientstil uden puls og med lange sammenbundne toner i brede klangflader. Der er tale om det mest suspense-prægede tema i udsendelsen; først og fremmest på grund af at tonerne bendes (vrides) frem og tilbage, hvilket blandt andet medfører, at man ikke kan orientere sig tonalt. ${ }^{10}$ Denne effekt skaber desuden dissonanser i forhold til den underliggende klangbund. Dette virker stærkest, da temaet bruges, ikke i forbindelse med Pia, men i det sidste kapitel om "Malous svære valg" godt 38 minutter henne i udsendelsen. Malou, der har besluttet at få sine raske bryster fjernet i en forebyggende operation, sidder her sammen med plastikkirurgen, men har tydeligvis svært ved at koncentrere sig om det, han siger. Musikken fortrænger dialogen og bliver her så "vredet" og dissonerende, at den kan give anledning til oplevelsen af et fysisk ubehag hos recipienten selv. Vi indtager dermed hendes subjektive position. Angsten trænger sig på.

Hvor den komponerede lydside i anslaget med de mange lydeffekter orienterer sig mod en mere ufokuseret og utryg stemning, bliver de fire musikalske temaer rettet imod de enkelte kvinders følelsesliv, hvilket skulle fremgå af eksemplerne her. Det skyldes som nævnt ikke musikkens ekspressivitet alene, men også de billeder og den dialog, der omgiver den, samt musikkens placering i det narrative forløb. Eksemplerne med horntemaet viser, hvordan betydningen af musikkens ekspressivitet på kamæleonens vis ændrer sig efter konteksten og derfor ikke kan analyseres løsrevet fra denne. Musikken knytter sig til nogle grundfølelser i fortællingen, men nuancerer dem eller toner dem i en bestemt retning. Helt overordnet repræsenterer musikken kvindernes angst, utryghed og ensomhed og er ligesom disse følelser næsten hele tiden til stede, selvom vi ser billeder af dagligdagens tilsyneladende lethed (shopping, legende børn, hyldeblomstsaftbrygning). Som recipienter genkender vi disse følelsestilstande og mærker dem måske selv. Vi lever os ind i dem via den komponerede lydsides strøm af musikalsk "liv". Musikken er diffus og uden tydeligt harmonisk center og er i konstant forandring med små ændringer ad gangen. Det giver anledning til oplevelsen af nuancerede og dynamiske følelsestilstande, som hele tiden forandrer sig sammen med musikken. Det er derfor ikke tilstrækkeligt udelukkende at bruge de mere afgrænsede kategoriale følelseskategorier som f.eks. tristhed og angst i forbindelse med beskrivelsen af musikkens betydningsgenerering i denne udsendelse. Hvad det så kan være for en slags følelser, musikken kommunikerer, kommer jeg nærmere ind på i det følgende.

\section{Musik og følelser}

Inden for de seneste fem-ti år har journalisterne fået en meget højt udviklet bevidsthed om vore egne virkemidler. Vi ved præcis, hvordan bestemte følelser kan fremkaldes - har vi et følsomt emne, fremhæves det med en sprød cembalo og en speakerstemme i et bestemt toneleje. (Bohr, 1998, s. 12).

Spørgsmål omkring sammenhængen mellem musik og følelser har optaget mennesket siden antikken. Musikalsk betydning bliver ofte forbun- 
det med følelser ikke mindst i den audiovisuelle kontekst, og man taler om musik som følelsernes sprog. En eller anden form for følelsesmæssig oplevelse er formodentlig en væsentlig grund til, at vi overhovedet lytter til musik, og man skulle derfor tro, at spørgsmålet stod centralt i musikvidenskaben. Men her er sammenhængen mellem musik og følelser stort set blevet negligeret gennem de sidste mange årtier. Det skyldes først og fremmest vægtningen af den bevidste analyse af mekanismerne i musikken over for den følelsesmæssige, som stadig ikke er en integreret del af musikvidenskaben, som den praktiseres i dag.

På trods af Bohrs selvsikre udtalelse i citatet ovenfor, så er det imidlertid vanskeligt "præcist" (jf. Bohrs ordvalg) at pege på sammenhængen mellem to så upræcise størrelser som musik og følelser. Der findes ingen konsensus om, hvad det er i musikken, der giver anledning til bestemte følelser, eller for den sags skyld, hvad følelser overhovedet er for noget. De følelsesmæssige reaktioner, der er lettest at forstå, er dem, der er direkte knyttet til vor biologiske overlevelse som f.eks. frygt. Følelser i forbindelse med musik er sværere at gøre rede for, og måske er musikalsk genererede følelser fundamentalt anderledes end andre følelser. Det varierer desuden meget, hvad det er, man kalder en følelsesmæssig reaktion i forbindelse med musik: At fornemme en spændingstilstand i kroppen, køligt at påskønne teknikken, at græde, at få gåsehud, at få associationer til en gammel kærlighedsaffære osv. Selvom forholdet mellem musik og følelser således næppe er så enkelt og entydigt, som det fremstår af citatet ovenfor, vil jeg i det følgende argumentere for, at der er en strukturel lighed i vores oplevelse af henholdsvis musik og følelser, som giver underlægningsmusikken privilegeret adgang til at kommunikere visse former for følelser.

Der eksisterer to teser i forbindelse med teoretiseringen omkring musik og følelser, der har rødder tilbage til de kvaliteter, man i det antikke Grækenland tilskrev musikken: Mimesis (imitationen og transformationen af en ydre realitet) og katharsis (renselsen af sjælen gennem en følelsesmæssig oplevelse).$^{11}$ I nyere forskning taler man parallelt hermed om henholdsvis expression-teorien overfor arousal-teorien eller kognitivisterne overfor emotivisterne. ${ }^{12}$ De overvejelser, man gennem tiden har gjort og stadig gør sig om musik og følelser, indskriver sig i denne problemstilling om, hvorvidt musik repræsenterer følelser, som genkendes af lytteren, eller om musik bevirker følte følelser hos lytteren. Disse to kan godt være sammenfaldende, men er det ikke altid - vi kan godt registrere og genkende den musikalsk formidlede ømhed eller kærlighed mellem Marianne og hendes mor i eksemplet fra Nesten en dødsdom uden dermed selv at føle den. Den følelse, som vi synes musikken udtrykker, er ikke nødvendigvis den følelse, der opstår i os, men kan godt være det - f.eks. i forbindelse med det fysiske ubehag, som de forvredne lyde kan give anledning til i scenen, hvor Malou er hos plastikkirurgen. Positionerne kan derfor være vanskelige at holde adskilte.

Når man i forbindelse med expression-teorien taler om, at musik udtrykker eller repræsenterer følelser, sker det ud fra forestillingen om, at de musikalske strukturer svarer til vores følelsesmæssige strukturer. Vores liv medfører mange forskellige emotioner, simultant og i forlængelse af hinanden. Disse komplekse relationer - denne emotionelle polyfoni - er flere steder beskrevet som havende visse ligheder med oplevelsen af musik. Der findes mere eller mindre radikale udgaver af denne opfattelse, f.eks. barokkens affektlære, hvor musikken blev betragtet som bærer af klart definerbare og velafgrænsede følelsesmomenter. Mere plausibel er opfattelsen af, at musik ikke direkte repræsenterer en konkret følelse, men at dens dynamiske form har formel lighed med følelsernes form. Den tankegang kan føres tilbage til Eduard Hanslicks Vom Musikalisch Schönen fra 1854. Oftest er det dog filosoffen Susanne K. Langer, der trækkes frem som repræsentant for expression-teorien med hendes tanker om, at musikken opnår semantisk betydning gennem symboliseringen af følelser - en betydning, der er væsentlig forskellig fra sprogets betydning.

Because the forms of human feeling are much more congruent with musical forms than with the forms of language, music can reveal the nature of feelings with a detail and truth that language cannot approach. (Langer, 1951, s. 155. Langers kursivering).

Over for expression-teorien står arousal-teorien, der tager afsæt i opfattelsen af, at musik ikke blot symboliserer eller repræsenterer, men også direkte fremkalder følelsesmæssige reaktioner i lytteren. Ifølge arousal-teorien har vores kognitive reaktioner i forbindelse med musik mange ligheder med den måde, vi i det hele taget reagerer på omverdenens lyde på. Hørelsen aktiveres ved, at lyde rammer 
trommehinderne. Det bevirker en tilstand af opmærksomhed, en arousal, og bevidstheden bliver opmærksom på, at der sker noget. Vores hørelse fokuserer derefter på hændelsen (hvad er kilden til lyden, hvor befinder den sig?) og opmærksomheden forhøjes og opretholdes af emotionel respons. Arousal manifesterer sig som fysiologiske forandringer i det autonome nervesystem, hvoraf flere kan måles. I løbet af en arousal er den elektriske modstand i huden formindsket, pupillerne udvides, vejrtrækningen bliver enten hurtigere, langsommere eller ustabil, blodtrykket og hjerterytmen har tendens til at stige, og der sker en forøgelse i musklernes spændingstilstand, som ofte ledsages af fysisk uro. Desuden bliver svedkondensering og fingertemperatur lavere. Disse "vækkelser" peger i retning af en eller anden form for biologisk bestemt forstadium til at være på vagt før en eventuel handling.

Psykologen Carol Krumhansl har gennemført nogle omfattende eksperimentelle undersøgelser, der bekræfter arousal-teorien (Krumhansl, 1997 og 2002). Flere af hendes resultater viser et gensidigt forhold mellem testpersonernes verbale beskrivelser af deres følelsesmæssige oplevelse af nogle musikeksempler og de fysiologiske reaktioner og aktiveringstilstande, der samtidig blev målt i deres autonome nervesystem. Et af resultaterne viste, at den triste musik bevirkede størst forandringer i blandt andet puls, blodtryk, og fingertemperatur. Musik, der blev beskrevet med følelsen frygt, viste størst udsving i blodgennemstrømningen, og den glade musik havde størst indvirkning på vejrtrækningen. Krumhansl kan dermed konkludere, at de musikalske følelser ser ud til at have deres eget mønster af fysiologiske symptomer, og at vi registrerer følelsen direkte ud fra disse fysiologiske ændringer i kroppen. Men resultaterne stemte ikke overens med undersøgelser af de ikke-musikalske følelsers fysiologi - dvs. at en ikke-musikalsk foranlediget følelse af glæde ikke viser de samme ændringer i vejrtrækningen, som den musikalsk foranledigede glædesfølelse. Så selvom vi bruger begreberne for de kategoriale følelser, når vi beskriver musikken, er der således noget, der tyder på, at musikalske følelser er forskellige fra disse.

Betegnelserne på de forskellige følelseskategorier virker dog også for afgrænsende på den flygtige, dynamiske musikalske oplevelse. Udviklingspsykolog Daniel N. Stern har imidlertid udviklet et begreb, med hvilket man kan fange denne dynamik. Det drejer sig om begrebet vitalitetsfolelser, som han udviklede, da han manglede en betegnelse for de følelseskvaliteter, som opleves over tid, og som bedst beskrives ved dynamiske eller kinetiske betegnelser såsom brusende, blegnende, flydende, eksplosiv, crescendo, decrescendo, bristende, langtrukne osv. (Stern, 1999a, s. 64). Vitalitetsfølelserne er amodale og kan således uddrages fra stimulusverdenen inden for alle sansemodaliteter. De er uden objekt og har en dynamisk struktur, der refererer til det samme generelle mønster - et mønster, der relaterer sig til bagvedliggende, amodale enheder af intensitet, tid og form. Stern beskæftiger sig ikke med oplevelsen af musik, men hans definition af vitalitetsfølelser støtter godt op om expression-teorien og Langers overvejelser omkring følelser som form og musikkens evne til at udtrykke disse former.

Stern udvikler begrebet på baggrund af undersøgelser af spædbarnets interaktion med omverdenen - især med moderen. Han refererer til flere af sine og andres observationer af, hvordan moderen ubevidst matcher babyens udtrykte vitalitetskonturer i lyd og bevægelse. Og efterligningen er dialektisk - også barnet forsøger via bevægelser og lyde at efterligne sin omverden. Når en forælder f.eks. trøster barnet, sker det over en intensitetsaftagende frase ("rolig, rolig, rolig" eller "så, så, så"). Det ledsages måske af tilsvarende intensitetsaftagende fysiske klap eller strøg på ryggen, hvorved der lydligt og taktilt opstår en fælleshed om bevægelsen (Stern, 1999a, s. 67f). Spædbarnet vil dermed opleve ensartede vitalitetskonturer, der resulterer i den samme vitalitetsfølelse. ${ }^{13}$ Vitalitetsfølelserne angår måden, hvorpå en handling udføres, mere end handlingens indhold. Stern bruger selv smilet som eksempel. Der er smil, som løfter sig jævnt og trægt, andre der eksploderer, og igen andre der begynder langsomt og pludselig bryder ud (Stern, 1999b, s. 71). Vi oplever også vitalitetsfølelser i forbindelse med menneskers kropsholdning og måde at bevæge sig på - igen noget vi har svært ved at sætte ord på, men som har en stor effekt på vores oplevelse, opfattelse og forståelse af omverden.

Sterns definition af vitalitetsfølelser kobler expression-teorien og arousal-teorien, idet han både taler om genkendelse af vitalitetskonturer i vores omverden og os selv, men også om, hvordan disse konturer kan omsættes direkte til følte vitalitetsfølelser. I min ph.d.-afhandling argumenterer jeg for, at det primært er i form at vitalitetsfølelser, vi oplever underlægningsmusik. Det sker på baggrund 
af en teori om, at vi grundlæggende oplever den musikalske ekspressivitet ud fra en kropslig erfaring med bevagelse, intensitet og genstande. Det er også disse oplevelseskvaliteter, der ligger til grund, når vi metaforisk beskriver musik som f.eks. tung, let, smidig, ru, grumset, klar, spændingsfyldt, forløsende, eller når vi taler om høje og dybe toner samt opadgående og nedadgående skalaer. Ligesom vitalitetsfølelser opleves musik over tid og ud fra de samme grundlæggende oplevelseskvaliteter af bevægelse, intensitet og form/overflade (Stern bruger som nævnt ovenfor begreberne intensitet, tid og form). Min pointe er, at de musikalske strukturer er auditive vitalitetskonturer, og at Sterns begreb om vitalitetsfølelser giver mulighed for at komme nærmere svaret på, hvordan underlægningsmusik opleves som følelser og stemninger. Det gælder både, når vi registrerer dem som tilstande i os selv, og når vi genkender dem hos personer eller i situationer på lærredet eller skærmen.

Via koblingen til billederne og det narrative forløb kan oplevelsen af musikkens strukturer imidlertid også indgå i mere fokuserede følelsesoplevelser, da denne kontekst tilbyder et objekt (f.eks. en person eller en hændelse) at knytte dem til. ${ }^{14}$ Som eksemplerne fra Nesten en dodsdom viste, vil de vitalitetsfølelser, som musikken genererer, automatisk koble sig til det visuelle, dialogen eller det narrative, hvor de grovere, kategoriale følelsesmæssige identifikationer ligger (kærlighed, ømhed, angst, frygt), og dermed bliver den følelsesmæssige oplevelse mere fokuseret. Men musikken vil dog samtidig strukturere, modulere og skabe resonans for den følelse, der registreres ud fra den audiovisuelle helhed, så vi oplever, at den audiovisuelle skildring stemmer mere overens med den måde, vi oplever verden omkring os på - jf. musikkens tunge melankolske toning af de glade ansigtsudtryk hos Marianne og hendes mor i Nesten en dodsdom.

Neurologen Antonio Damasio har uafhængigt af Stern udviklet et begreb svarende til vitalitetsfølelser, som han kalder baggrundsfolelser. Han siger blandt andet om disse følelser: "background feelings help define our mental state and color our lives" (Damasio, 2000, s. 287). I citatet nedenfor sammenligner han baggrundsfølelserne med oplevelsen af minimalistisk musik og bekræfter dermed ligheden mellem disse følelser og oplevelsen af den enkle, tilbagetrukne underlægningsmusik, der netop oftest er minimalistisk i sit udtryk.
I call it background feeling because it originates in "background" body states rather than in emotional states. It is not the Verdi of grand emotion, nor the Stravinsky of intellectualized emotion but rather a minimalist in tone and beat, the feeling of life itself, the sense of being (Damasio, 1994, s.150).

Hvis man accepterer, at underlægningsmusikken kan kommunikere disse følelsesnuancer, så er der altså, hvis man skal anvende Damasios ord, tale om, at den kan kommunikere intet mindre end "følelsen af livet selv og en fornemmelse af at være”. Jeg vil i forlængelse heraf hævde, at underlægningsmusik kan være med til at fremme oplevelsen af noget virkeligt - tilføre en vitalitet til den audiovisuelle helhed, som ikke kan repræsenteres i billeder og tale alene. I forbindelse med tv hersker der en grundlæggende opfattelse af, at fakta kommunikeres gennem ordet og dokumenteres via billedet. Underlægningsmusikken kan imidlertid formidle nogle lyriske og følelsesmæssige nuancer, der er en yderst vigtig del af den skildrede virkelighed. Disse nuancer findes også i mimik, gestik og stemmeføring, men musikken har en særlig diskret og præcist måde at formidle disse følelser på - jf. det tidligere citat af Susanne K. Langer.

\section{Musik i tv-dokumentarer}

Jeg vil på baggrund af det foregående trække nogle problemstillinger og synspunkter frem angående musikkens rolle i tv-dokumentaren - en rolle, der ofte bliver defineret negativt som manipulerende. Men frem for skjulte bagtanker hos tilrettelæggeren bunder denne oplevelse snarere i recipientens manglende refleksion over, hvordan og hvad musik kommunikerer. I modsætning til den rationelle, intellektuelle, visuelle og verbale erfaring er vi nemlig typisk ikke vant til analytisk refleksion i forbindelse med den auditivt funderede æstetiske og følelsesmæssige erfaring. Vores film og tv-musikalske erfaring er så omfattende, at de fleste mennesker er yderst kompetente og lynhurtige til at trække betydning ud af musikken, men det foregår på et før-refleksivt perceptionsniveau. Som jeg var inde på med begrebet vitalitetsfølelser, så har vores måde at opleve underlægningsmusik på fællestræk med den måde, vi aflæser kropssprog, mimik og andre ikke-verbale kommunikationsformer på. Uden at være bevidste om det, er vi eksperter $i$ at 
betragte og skabe betydning ud fra andres gestik, mimik og stemmeføring, og vi drager ofte vidtrækkende slutninger på baggrund af disse forbevidste registreringer af blandt andet vitalitetskonturer/ -følelser. Videnskabelige forsøg af blandt andre den amerikanske psykolog Albert Mehrabian har vist, at det betyder langt mere for os, hvordan en persons ansigtsudtryk og stemme er, end det, hun rent faktisk siger (Vedfelt, 1996, s. 158). ${ }^{15}$ På samme måde med underlægningsmusikken. Selvom en person skildres visuelt og verbalt som barbarisk og usympatisk kan en mild, afbalanceret, rolig musik eller en munter lirekassemusik ændre og nuancere oplevelsen af denne skildring ligesom musikken farver eller toner de glade blikke mellem Marianne og hendes mor i en melankolsk retning i eksemplet fra tidligere.

I udgangspunktet er underlægningsmusik i dokumentariske fremstillinger et paradoks: Den er et realismebrud, da den ikke er en naturlig del af den skildrede virkelighed. Men samtidig kan den være med til at gøre den fremstillede virkelighed mere realistisk via dens kommunikation af vitalitetsfølelser. Som recipienter accepterer vi ofte ukritisk dette paradoks, hvilket jeg mener kan forklares ved, at musikkens affektive kvaliteter er konsistente med det diegetiske univers, selvom dens akustiske aspekter ikke er det - et argument psykolog Annabel J. Cohen tidligere har fremlagt i forbindelse med fiktionsfilm (Cohen 1999, s. 366f). Vi skelner ikke mellem den information, der opstår ud fra henholdsvis musikken og den øvrige audiovisuelle kontekst, men oplever det som en helhed. Og i denne helhed er det musikkens affektive betydning, der giver mening, og dermed den hjernen lægger mærke til, mens den ignorerer eller svækker musikkens akustiske kilde. ${ }^{16}$ For eksempel kan den implicitte reception af scenen i Nesten en dodsdom, hvor Malou er hos plastikkirurgen, være følgende: Jeg oplever en anspændt knugen og en fornemmelse af angst (at følelsen i virkeligheden opstår ud fra den underliggende musik er irrelevant og ignoreres). Hvis jeg selv sad med valget mellem at få mine raske bryster fjernet eller at leve videre med en stor risiko for at dø af kræft, ville jeg også opleve disse følelser. Den følelsestilstand, jeg oplever, stemmer således overens med situationen, altså fremstår situationen virkelig for mig. ${ }^{17}$ Der opstår her en illusorisk foreningsproces mellem musik og kontekst, hvor den affekt, der opstår ud fra de musikalske strukturer, kobler sig til det visuelle og narrative forløb og fremmer en indlevelse i Malous situation. Man kan sige, at der i den kognitive bearbejdning af de musikalske stimuli foretages en form for førbevidst "realitetstest", før musikkens betydning får adgang til den narrative konstruktion. Havde vi i scenen med Malou i stedet hørt et sprælskt ragtime-tema, ville musikken have svært ved at slippe igennem realitetstesten, da denne type musik ville gøre for meget modstand i forhold til fortællingens helhed. ${ }^{18}$ Slipper musikken ikke igennem realitetstesten, vil vores bevidste opmærksomhed typisk rettes mod musikkens akustiske kvaliteter, hvorved illusionen om det realistiske univers brydes. Til gengæld kan der hermed opstå en opmærksomhed på musikkens tilstedeværelse, som gør, at man kan forholde sig refleksivt til dens betydning, f.eks. som en bevidst kommentar fra afsenderes side.

Således anvender dokumentarserien Drengene fra Vollsmose (TV 2, 2002) et indledende tema, som efter min mening gør tilpas meget modstand i realitetstesten til også at skabe en opmærksomhed på musikkens tilstedeværelse og betydning. Musikken er komponeret af Kåre Bjerkø og består af en melodi spillet på musette (fransk type trækharmonika) med et upbeat-akkompagnement (dvs. en markering af de ubetonede slag i takten) på el-klaver og en rytme-del bestående af stortrommeslag på det første slag i takten og en shaker på alle ottendedelene (de hurtige underinddelinger). Det er ikke den musik, der falder én først ind i forbindelse med en dokumentarudsendelse, og slet ikke en, der omhandler de kriminelle andengenerationsindvandrere i det belastede Vollsmosekvarter i Odense. Ser vi på musikkens sociokulturelle kodninger, giver musetten typisk associationer til Frankrig og noget maritimt. Men den musikalske stil leder her også tankerne hen på danske folkekomedier, der idyllisk skildrer et lille lokalt storbymiljø med en masse skæve eksistenser; "vi har det godt her - vi holder sammen". Associationer til filminstruktøren Erik Clausens film og tv-serien Huset på Christianshavn går igen, når jeg i forskellige sammenhænge har spurgt til andres oplevelse af dette tema. Musikkens ekspressivitet udtrykker harmonisk idyl, og melodiens spring opad, sekvenseringerne samt de lette upbeat-markeringer giver en glad og positiv stemning. Det stemmer overens med billedsiden, der betoner det glade og det sociale ved f.eks. i indledningen til 3. afsnit at vise dansende, legende børn, fjantede teenagepiger og en gruppe småsludrende muslimske mødre med klapvogn. Den 
positive stemning klinger med videre ind $\mathrm{i}$ afsnittets første scene og fremhæver den venskabelige og uformynderiske tone mellem den småkriminelle Amer og skolelederen Olav Nielsen, der er seriens hovedpersoner.

Vi făr med denne indledning en helt anden opfattelse af de mennesker, der skildres her, i forhold til hvordan unge andengenerations-indvandrere og Vollsmose sædvanligvis skildres i medierne, og der skabes en positiv indstilling til indholdet allerede fra begyndelsen af udsendelsen. I kraft af musikkens glade udtryk samt folkekomediekodningen opleves de som mennesker med gode og dårlige sider i et nærmiljø, og den i medierne fremherskende "dem og os"-dikotomi opløses. Musikken skaber modvægt og udligner dermed eventuelle fordomme og giver, netop fordi den gør en vis modstand i realitetstesten, oven i købet anledning til refleksion over vore egne holdninger til og opfattelser af det fremstillede emne inden for udsendelsens egen kontekst.

Musikkens rolle i dokumentarudsendelser er derfor ikke begrænset til at medvirke til oplevelsen af ind- eller medlevelse med udsendelsens personer, hvilket var en vigtig del af musikkens betydning i Nesten en døddsdom. Musikken kan i visse tilfælde også skabe et associationsrum for analytisk distance og refleksion. Underlægningsmusik kan med andre ord både skabe rum for følelsesmæssig resonans og tankemæssigt ræsonnement i forhold til det emne og de personer, der præsenteres, og i forhold til de forudindtagede holdninger, recipienten eventuelt måtte møde udsendelsen med.

Jeg vil her til sidst kort vende tilbage til begrebet katharsis, som jeg var inde på tidligere i forbindelse med, at musik kan give anledning til en følelse. Selve renselseselementet i dette begreb kan efter min mening nemlig også bringes i spil i forbindelse med underlægningsmusikkens rolle. Undersøgelsen af de 37 dokumentarudsendelser i min ph.d.-afhandling viste, at musikken i dokumentarudsendelser ofte er placeret i overgangene fra en scene til en anden, når et nyt kapitel skal begynde, eller et nyt argument bringes på banen. På det visuelle plan hæves vi ofte i bogstaveligste forstand op over begivenhederne ved billeder i fugleperspektiv, mens en voice over opsummerer eller leder videre. Samtidig med at musikken her har en sammenbindende funktion, skaber den i disse overgange rum for en kort eftertanke og (emotionel) evaluering af det, vi er blevet præsenteret for. I særligt følelses- provokerende udsendelser som f.eks. den meget omdiskuterede De pedofile danskere (TV 2 dok., 2000) kan musikken ligefrem fungere som en slags ventil for de ophobede, emotionelle spændinger. Udsendelsen handler om, hvordan journalisten Jakob Billing med mikrofon og skjult kamera infiltrerer det pædofile miljø i Danmark ved inkognito at melde sig ind i den lovlige forening Pedofilgruppen. Emnet, den seksuelle udnyttelse af børn, er i denne udsendelse så følelsesmæssigt anstrengende og belastende, at musikkens funktion som ventil for de ophobede følelser bliver særlig tydelig. Vi holder vejret, mens Billing sidder og ser film hjemme hos den pædofile "Per", eller når han erfarer, at en mand gennem mange år har misbrugt sin egen datter. Den efterfølgende musik tilbyder sig her som samlende medium for de diffuse emotionelle energier, som opstår under receptionen. Først når musikken lyder i overgangen til den efterfølgende scene, får vi mulighed for at få taget trykket af den ophobede spænding, og dermed give plads til nye informationer. Selvom lydtekniker Thomas Gulyás' musik i De pedofile danskere først og fremmest er spændingsopbyggende suspensemusik karakteriseret ved dissonerende intervaller og kromatik i et skingert, højt leje, kan denne musik i kraft af sin placering spille en dobbeltrolle og samtidigt virke spændingsforløsende, idet den tilbyder sig som kanal for de følelser, fortællingen genererer.

Indtager man en kritisk holdning til underlægningsmusikken, kan man hævde, at der med denne ventilfunktion er tale om en teflonæstetik, der medfører at de seriøse problematikker "preller af" på recipienten frem for at virke befordrende for et engagement i kampen mod pædofili eller en aktiv deltagen i diskussionen om foreningsfriheden i Danmark. Men ser man mere generelt på underlægningsmusikkens funktion i dokumentarprogrammer, kan man også argumentere for det modsatte: At netop musikken er i stand til at "prikke hul" og dermed lade udsendelsens indhold trænge ind under huden på recipienten, hvilket er en vigtig forudsætning for et (kritisk) engagement. Konkluderende vil jeg således hævde, at underlægningsmusik i dokumentarudsendelser befordrer en emotionaliserende men samtidig en engagerende æstetik, der via en både emotionel og kognitiv intensivering giver mulighed for en dybere udforskning af den fremstillede virkelighed. 


\section{Litteratur}

Aristoteles (1992), Poetik, på dansk ved Poul Helms, København: Hans Reitzels Forlag.

Bohr, Morten (1998). Interview i Weekendavisen 3.-7. april, sektion 1 side 12 .

Bondebjerg, Ib (2000), I dialog med den danske virkelighed, Bruun, Frandsen, Søndergaard (red.) TV 2 på skermen, København: Samfundslitteratur.

Cohen, Annabel J. (2000), Film Music. Perspectives from Cognitive Psychology, Buhler, Flinn og Neumeyer (red.), Music and Cinema, Wesleyan University Press, s. 360-378.

Cohen, Annabel J. (1990), Understanding Musical Soundtracks, Empirical Studies of the Arts, vol. 8 nr. 2, s. 111-123.

Cook, Nicholas (1998), Analysing Musical Multimedia, Oxford: Clarendon Press.

Damasio, Antonio R. (1994), Descartes' Error. Emotion, Reason and the Human Brain, New York: G.P. Putnam.

Damasio, Antonio R. (2000), The Feeling of What Happens. Body, Emotion and the Making of Consciousness, London: Vintage

Hanslick, Eduard (1885), Det Skjønne i Musikken, Bergen: Chr. W. Huuns Forlag

Krumhansl, Carol (2002), Music: A Link Between Cognition and Emotion, Current Directions in Psychological Science, vol. 11 nr. 2, s. 45-51.

Krumhansl, Carol (1997), An Exploratory Study of Musical Emotions and Psychophysiology, Canadian fournal of Experimental Psychology, vol. 51 nr. 4, s. 336-352.

Have, Iben (2004), Det musikalske underspil: En undersøgelse af underlagningsmusikkens betydning, belyst gennem den journalistiske to-dokumentar, ph.d.-afhandling, Århus Universitet.

Langer, Susanne K. (1951), Philosophy in a New Key, New York: New American Library.

Langkjær, Birger (2000), Den lyttende tilskuer, København: Museum Tusculanum.

Larsen, Peter Harms (1990), Faktion som udtryksmiddel, København: Forlaget Amanda.

Sloboda og Juslin (red.) (2001), Music and Emotion, Oxford: Oxford University press.

Smith, Jeff (1999), Movie Music as Moving Music, Plantinga og Smith (red.), Passionate Views - Film, Cognition and Emotion, Baltimore: The John Hopkins University Press.

Stern, Daniel N. (1999a), Barnets interpersonelle univers, København: Hans Reitzels Forlag. Opr. 1985.

Stern, Daniel N. (1999b), Vitality Contours: The Temporal Contour of Feelings as a Basic Unit for Constructing the Infant's Social Experience, P. Rochat (red.), Early Social Cognition, London: Lawrence Erlbaum Associates.

Vedfelt, Ole (1996), Bevidsthed, København: Gyldendal.

\section{Tv-udsendelser}

De pedofile danskere, Jakob Billing og Henrik Grunnet, TV 2 dok., 30. oktober 2000.

Drengene fra Vollsmose 1-3, Jørgen Flindt Pedersen og Anders Riis-Hansens, TV 2, 14. 21. og 28. februar 2002.

Nesten en dødsdom, Kay Bæckmann Nielsen, TV 2 dok., 16. oktober 2000.

\section{Noter}

1 Jeg anvender betegnelsen "seriøs" dokumentar i modsætning til det mere underholdningsprægede "reality-tv". Der findes forskellige former for seriøs dokumentar (journalistisk dybdeborende, observerende, portrætterende osv.). Generelt henvises til den type dokumentarudsendelser, der sendes under redaktionerne DR-dokumentar og TV 2 dok. Drengene fra Vollsmose er en undtagelse, men blev som de øvrige sendt i prime time på dansk public service-tv.

2 Afhandlingen blev indleveret ved Afdeling for Musikvidenskab, Århus Universitet i 2004, og er bygget op omkring tre hovedspørgsmål: Hvordan genererer musik betydning?; hvordan gør den det i en narrativ, audiovisuel kontekst?; hvilken rolle spiller underlægningsmusik i tv-dokumentarer? Den aktuelle artikels grundlæggende materiale stammer fra afhandlingen, men visse pointer er blevet videreudviklet.

3 Med komponeret non-diegetisk lyd forstår jeg lyd, der er "lagt på", og som ikke udspringer af eller kobles direkte til udsendelsens fysiske rum.

4 I TV 2 dok.s udsendelser var der musik i 32,5\% af tiden og i DR-dokumentars i $17 \%$. I de 9 observerende dokumentarer af Lars Engels lå musikforbruget på gennemsnitligt 4\%. Fraregnes disse udsendelser ligger DRdokumentars gennemsnitlige musikforbrug på $25 \%$.

5 Koblingen mellem musik og den øvrige audiovisuelle kontekst i betydningsgenereringen bliver kun overfladisk berørt i denne artikel, men behandles indgående i ph.d.-afhandlingen Det musikalske underspil (Have, 2004).

6 Oplysningerne omkring produktionen stammer fra en e-mail-udveksling med udsendelsens redigeringstekniker, Morten Stæhr.

7 Den næstmest anvendte type musik er den melodiske ballade med et akustisk klingende, melodibærende instrument, ofte ledsaget af en underliggende string pad. I den melodiske ballade er melodikken mere sangbar end i den elektroniske ambientmusik og får mulighed for at udvikle sig inden for en genkendelig form. Af øvrige underlægningsmusikalske tendenser i de 37 dokumentarudsendelser kan nævnes brugen af symfonisk filmmusik, centraleuropæisk klassisk musik samt anden "etnisk" musik, der knytter sig til forskellige geografiske eller historiske kulturer (Have, 2004, s. 167ff)

8 Et dissonerende interval er, når to toner "skurrer" mod hinanden i modsætning til konsonerende intervaller, hvor tonerne indgår i en "harmoni". Kromatik betyder, at melodien eller motivet bevæger sig i halvtonetrin. Ostinat (it. ostinato $=$ stædig) er betegnelsen for en stadig gentagelse af den samme figur oftest i det samme stemmeleje.

9 Dryppe-lydene ligger på forskellige toner, hvilket er endnu et eksempel på den svære skelnen mellem musik og lydeffekter. Lydene er i øvrigt taget fra nummeret "Echo" fra Pink Floyds album Meddle.

10 Bending af tonerne er en hyppig anvendt suspense-effekt i dokumentarudsendelser. Jf. f.eks. En morder vender hjem og Bag lukkede dore. Begge fra TV 2 dok. 2000.

11 Begreberne mimesis og katharsis er fra Aristoteles' Poetik (1992). 
12 Jf. Sloboda og Juslin (2001, s. 32f), Nicholas Cook (1998, s. 88) og Jeff Smith (1999, s. 151f)

13 Stern skelner ikke mellem vitalitetskonturer og vitalitetsfølelser i Stern (1999a). Denne skelnen introducerer han først i sin artikel fra 1999b.

14 Hvordan denne fokusering finder sted er uddybet hos Birger Langkjær (2000), særligt i kapitlet "Den fokuserede ekspressivitet: Person, situation og tilskuer", s. 69-99.

15 Vedfelt henviser til Albert Mehrabians forsøg fremlagt i Silent Messages 1981, s. 76-77. Resultaterne viste, at vores indstilling til en samtalepartner ikke i så høj grad bygger på det vedkommende siger, men i højere grad på stemmens klang og ansigtsudtrykket. Omregnet i procent viste Mehrabians forsøg, at det verbale udtryk udgjorde
$7 \%$, stemmes kvaliteter 38\% og ansigtsudtrykket 55\% af det samlede indtryk.

16 Der er selvfølgelig en generalisering, eftersom nogle lyttere er mere bevidste om musikkens strukturer end andre, og eftersom noget underlægningsmusik lægger op til en mere bevidst perception end andet.

17 Et lignende eksempel findes hos Annabel J. Cohen (1990, s. 118).

18 Anvendelsen af begrebet "reality test" i forbindelse med perceptionen af underlægningsmusik i fiktions-film introduceres af Annabel J. Cohen (1999, s. 367).

Iben Have er adjunkt, ph.d., ved Institut for Informations- og Medievidenskab, Århus Universitet. 